\title{
ANALISIS KEMAMPUAN BERPIKIR KREATIF MATEMATIS DITINJAU DARI SELF-EFFICACY DALAM PEMBELAJARAN DISCOVERY LEARNING
}

\author{
Mathematical Creative Thinking Skills Analysis in Terms of Self-Efficacy in Discovery \\ Learning \\ Nurjali $^{1 *}$, Muhammad Rizqi ${ }^{2)}$ \\ ${ }^{1}$ SMA Negeri 4 Cirebon, Kota Cirebon, Jawa Barat, nurjalisalam123@gmail.com \\ ${ }^{2}$ SMA Negeri 4 Cirebon, Kota Cirebon, Jawa Barat, beani.rizqi@gmail.com
}

\begin{abstract}
The purpose of this study is to provide an overview of the analysis results on creative thinking skills in terms of self-efficacy in discovery learning assisted by open-ended questions. The method used is descriptive qualitative. Data collection techniques in this study were carried out through direct school activities. Data was collected by means of tests of mathematical creative thinking skills and documentation. The population of this study is class VIII at the MTS Islamic Center with the research sample are class VIII-A. The research results are (1) students with high self-efficacy, there are five students belong to the first group, three students belong to the second group and no student belongs to the third group, (2) students with moderate self-efficacy, there are four students belong to the first group, two students belong to the second group, and no student belongs to the third group, (3) students with low self-efficacy, there are no student belongs to the first group, no student belongs to the second group and there are only six students belong to the third group.
\end{abstract}

Keywords: discovery learning, mathematical creative thinking skills, open-ended questions.

\begin{abstract}
ABSTRAK
Tujuan penelitian ini adalah memberikan gambaran tentang hasil analisis kemampuan berpikir kreatif ditinjau dari self-efficacy pada pembelajaran discovery learning berbantuan soal open-ended. Adapun Metode yang digunakan adalah penelitian deskriptif, teknik pengumpulan data dalam penelitian ini dilakukan melalui kegiatan langsung disekolah. Pengumpulan data dilakukan dengan tes kemampuan berpikir kreatif matematis, dan dokumentasi. Populasi penelitian ini yaitu kelas VIII di MTS Islamic Center dengan sampel penelitian kelas VIII-A. Hasil penelitian yang diperoleh adalah sebagai berikut. Adapun hasil penelitian yang diperoleh sebagai berikut (1) siswa dengan self-efficacy tinggi, terdapat lima siswa yang tergolong kelompok pertama, ada tiga siswa yang tergolong kelompok kedua dan tidak ada siswa yang tergolong kelompok ketiga, (2) siswa dengan self-efficacy sedang, terdapat empat siswa yang tergolong kelompok pertama, ada dua siswa yang tergolong kelompok kedua, dan tidak ada siswa yang tergolong kelompok ketiga, (3) siswa dengan self-efficacy rendah, tidak ada siswa yang tergolong kelompok pertama, tidak ada siswa yang tergolong kelompok kedua dan hanya ada enam siswa yang tergolong kelompok ketiga.
\end{abstract}

Kata kunci: kemampuan berpikir kreatif matematis, pembelajaran discovery learning, soal open-ended

\section{PENDAHULUAN}

Pada abad 21 terdapat banyak sekali tantangan dalam berbagai bidang, oleh sebab itu diperlukan sumber daya manusia yang unggul. Sehingga dibutuhkan kompetensi inti dalam menghadapi tantangan abad ini. Terdapat beberapa kompetensi inti yang ditekankan yaitu learning and inovation skills, digital literacy, dan life and carrier skills (Nizam, 2016). Learning and inovation skills terdiri dari kemampuan berpikir kritis, kemampuan berpikir kreatif, komunikasi, dan kolaborasi. Digital literacy adalah kemampuan untuk memanfaatkan teknologi informasi dan komunikasi (ITC), sedangkan life and carrier skills adalah keterampilan sosial, fleksibilitas, inisiatif, kepemimpinan, produktif, dan pembelajaran sepanjang hayat. Adapun menurut Hosnan (2016) terdapat beberapa hal yang dapat dilakukan untuk membuat sumber daya manusia menjadi lebih berkualitas dalam proses pendidikan ada tiga unsur yaitu kurikulum, guru dan siswa. Pendidikan adalah tempat memperoleh pengetahuan dan keterampilan yang dapat digunakan untuk menghadapi permasalah yang ditemukan 
sehari-hari dalam kehidupan (Yurniwati \& Hanum, 2017), oleh karena itu proses pembelajaran di satuan pendidikan harus diselenggarakan secara interaktif, inspiratif, menyenangkan, menantang, menumbuhkan motivasi siswa untuk berperan aktif, serta memberikan ruang yang cukup bagi prakarsa, kreativitas, dan kemandirian sesuai dengan bakat, minat, dan perkembangan fisik serta psikologis siswa. Salah satu pelajaran yang diajarkan dalam kurikulum 2013 adalah pelajaran matematika. Masih banyak siswa yang menganggap matematika sebagai pelajaran yang sulit dipahami, sehingga sering menimbulkan berbagai masalah rumit untuk dipecahkan, dan berdampak pada rendahnya hasil belajar siswa (Saironi \& Sukestiyarno, 2017).

Hal tersebut dapat dilihat dari hasil Ujian Nasional Berbasis Komputer (UNBK) untuk SMP sederajat yang dikeluarkan oleh puspendik khususnya pada pelajaran matematika tahun 2018, menyatakan bahwa rata-rata nilai Ujian Nasional (UN) mengalami penurunan dari 50,31 pada tahun 2017 menjadi 43,34 dengan nilai maksimal adalah 100. Rendahnya hasil rata-rata UNBK dikarenakan kurangnya kemampuan berpikir tingkat tinggi atau Higher Order Thinking Skills (HOTS). Menurut Isrok'atun (2014) seseorang akan mampu menyelesaikan masalah apabila memiliki kemampuan yang memadai, meningkatan rata-rata nilai UN dan kemampuan berpikir tingkat tinggi maka pendidik harus mengasah kemampuan siswa supaya dapat berpikir tingkat tinggi atau HOTS. Kemampuan berpikir tingkat tinggi atau Higher Order Thinking Skills (HOTS) terdiri atas berpikir kreatif, berpikir kritis, pemecahan masalah, komunikasi, koneksi, dan penalaran matematika, serta metakognitif (Liliasari, Supriyanti \& Hana, 2016). Salah satu upaya untuk menciptakan kemampuan berpikir tingkat tinggi pada mata pelajaran matematika adalah mengasah kemampuan berpikir kreatif, yang berarti siswa diharapkan menjadi manusia yang kreatif. Sehingga siswa harus mempunyai kemampuan berpikir kreatif. Kreativitas adalah kemampuan yang tidak ternilai harganya dan sangat esensial di abad 21 (Novia, 2016; Purnama, 2017), selain itu menurut Riski, et al. (2017) \& Maulidia, et al. (2019) kreativitas perlu dimiliki oleh setiap orang, tidak hanya dalam sekolah. Vygotsky menyebutkan bahwa kreativitas merupakan salah satu kegiatan mekanis yang penting dalam mengkonstruksi pengetahuan baru siswa (Akgul \& Kahveci, 2016), sedangkan menurut Dewi \& Masrukhan (2018) Kreativitas merupakan produk dari aktivitas berpikir kreatif yang dapat memunculkan dan menghasilkan suatu ide baru. HOTS merupakan salah satu hal yang wajib dimiliki siswa pada abad ke-21 ini, karena kreativitas merupakan hasil dari berpikir kreatif, merupakan keterampilan yang sangat penting dalam mengembangkan bakat siswa (Peng, et al., 2013).

Faktor lain untuk mencapai kesuksesan dalam pelajaran matematika adalah faktor psikologi siswa khususnya self-efficacy (Subaidi, 2016). Laili \& Rahmawati (2015); Najha, et al. (2017) \& Khaerunisak, et all. (2017) menyatakan bahwa keyakinan seseorang dalam mengkoordinir dan mengarahkan kemampuannya dalam mengubah serta menghadapi situasi disebut self-efficacy. Menurut Mareta \& Kusumawati (2014) Self-efficacy memegang peranan penting dalam kemajuan pendidikan karena self-efficacy akan membantu siswa merasa percaya pada kemampuan diri yang mereka miliki, serta mampu menangani secara efektif kesulitan yang mereka hadapi dalam pengalaman belajar. Konstruksi psikologis seperti self-efficacy adalah sifat pikiran yang tidak dapat diamati tetapi ini adalah subjek yang menarik untuk diamati bagi para ahli dan peneliti (Mogapi, et al., 2017).

Berdasarkan hasil wawancara dengan guru matematika di SMK Satya Mandala Cirebon didapatkan bahwa siswa kelas $\mathrm{X}$ hanya diberikan pembelajaran dengan cara berpusat pada guru, siswa tidak terlalu aktif terlibat dalam proses pembelajaran. Hal tersebut menunjukkan bahwa belum terlaksananya proses pembelajaran yang dianjurkan dari kurikulum 2013 yaitu merekomendasikan pembelajaran yang membuat siswa lebih aktif dalam proses pembelajaran. Selain itu, kurangnya pemberian informasi bahwa matematika adalah dasar untuk kemampuan keterampilan dalam pelajaran lainnya menjadikan siswa tidak mementingkan mata pelajaran matematika. Sejalan akan hal itu berdasarkan penelitian yang telah dilakukan oleh Rizqi, M. (2020) diperoleh bahwa siswa perlu lebih dilibatkan aktif dalam setiap proses pembelajaran agar hasil pembelajaran yang diharapkan bisa lebih tercapai, adapun menurut Rizqi, M., Suyitno, H., \& Dwijanto, D. (2021) dimana siswa belum terbiasa mengerjakan soal-soal yang bervariasi dan siswa belum terbiasa 
mengerjakan soal yang jawabannya lebih satu, sehingga saat diberikan soal seperti itu maka hasil yang diperoleh tidak sesuai harapan.

Terkait pemasalahan tersebut masih dapat diupayakan untuk meningkatkan kemampuan berpikir kreatif, maka diperlukan model pembelajaran dan pendekatan yang sesuai. Menurut Rochmad \& Masrukhan (2016) pendukung utama dalam keberhasilan pembelajaran yang dilakukan di kelas karena guru atau dosen menggunakan model pembelajaranyang tepat, bervariasi, mengajar dengan baik (good teaching) dan menggunakan pertanyaan yang baik (good question). Salah satu model pembelajaran yang sesuai dengan kurikulum 2013 yang pembelajarannya berpusat pada siswa salah satu model pembelajarannya adalah discovery learning. Penggunaan discovery learning menibulkan siswa lebih aktif dalam proses pembelajaran, seperti yang dinyatakan oleh Irmayanti, et al. (2014) bahwa dengan menggunakan discovery learning siswa belajar secara aktif dalam memperoleh pembelajaran baru dan guru menjadi fasilitator untuk mengarahkan siswa. Discovery learning diyakini dapat meningkatkan kesuksesan dan keterampilan pembelajaran lebih baik dari pada metode pembelajaran tradisional atau ekspositori (Rahayu et al., 2014; Bailey et al., 2012). Oleh karena itu, dibutuhkan pembelajaran yang dapat meningkatkan self-efficacy siswa, antara lain model pembelajaran yang menuntut siswa untuk aktif, dan bebas mengkonstruksi pengetahuannya (Wulandari et al, 2015; Puspita et al; 2016; Rosidi, 2016 \& Putri et al, 2017). Oleh sebab itu, pembelajaran discovery learning diduga mampu meningkatkan kemampuan berpikir kreatif matematis.

Selain model pembelajaran salah satu cara untuk merangsang kreativitas siswa dan self-efficacy, guru dapat menggunakan soal open-ended. Soal open-ended adalah salah satu pendekatan dalam pembelajaran matematika yang memberikan kebebasan berpikir kepada siswa secara aktif dan kreatif (Muhsinin, 2013). Kowiyah (2016: 69) juga menjelaskan bahwa soal open-ended dapat memberi kesempatan kepada siswa untuk memperoleh pengetahuan, pengalaman, menemukan, menggali, dan memecahkan masalah dengan beberapa teknik. Berdasarkan uraian tersebut, dapat diketahui bahwa siswa belum dapat menyelesaikan masalah terbuka dengan tepat, ada juga yang tidak selesai dalam pengerjaannya. Selain itu, siswa kurang memiliki kepercayaan diri (self-efficacy) untuk menyelesaikan masalah tersebut. Pada penelitian ini akan diteliti mengenai "Creative Thinking Ability Analysis and Self-Efficacy in Learning Assisted Discovery Learning with Open-Ended Question".

\section{METODE}

Pada penelitian ini menggunakan menggunakan metode penelitian deskriptif. Menurut Setyosari, H.P (2016), berpendapat bahwa penelitian deskriptif digunakan untuk memperoleh gambaran suatu kondisi, kejadian, objek atau segala sesuatu yang terkait dengan penelitian. Sejalan akan hal tesebut menurut Rizqi, M. (2020) jenis penelitian deskriptif memiliki teknik pengumpulan data yang dilakukan dengan pengumpulan data melalui study literature (skripsi, tesis, buku teks, jurnal).

Populasi dalam penelitian ini adalah siswa kelas VIII di MTS Islamic Center tahun ajaran 2019/2020. Sampel penelitiannya yaitu VIII A, serta diambil dari masing-masing kelas yang memiliki selfefficacy yang tergolong rendah, sedang dan tinggi, oleh sebab itu setiap kelas akan dipilih dua siswa yang memiliki self-efficacy yang tergolong rendah, sedang dan tinggi dari VIII A. Waktu pengambilan data dilakukan setelah siswa sudah digolongkan sesuai dengan self-efficacynya. Instrumen yang digunakan yaitu angket wawancara, dokumentasi, dan hasil pekerjaan siswa. Teknik analisis data kualitatif dilaksanakan dengan menggunakan empat langkah yaitu melalui uji keabsahan data, reduksi data, penyajian data, dan penarikan simpulan. 


\section{HASIL DAN PEMBAHASAN}

\section{Gambaran Kemampuan Berpikir Kreatif Matematis ditinjau dari self-efficacy}

Penentuan subjek penelitian diperoleh dari angket self-efficacy matematika. Sebelum pembelajaran diberikan perlakuan atau sebelum melakukan proses pembelajaran, terlebih dahulu mengelompokkan siswa berdasarkan self-efficacy matematika yang dimiliki. Pengelompokan self-efficacy matematika dikelompokkan menjadi siswa yang mempunyai self-efficacy matematika tinggi, sedang, dan rendah. Berikut data pengelompokkan siswa berdasarkan self-efficacy diperoleh dari pengisian angket, adapun kategori pengelompokkannya dari self-efficacy dipaparkan pada Tabel 1.

Tabel 1. Pengelompokkan siswa berdasarkan self-efficacy

\begin{tabular}{llllllll}
\hline No & Nama & Nilai Postest & Self-Efficacy & No & Nama & $\begin{array}{l}\text { Nilai } \\
\text { Postest }\end{array}$ & Self-Efficacy \\
\hline 1 & E-22 & 83,75 & Tinggi & 17 & E-4 & 58,75 & Sedang \\
\hline 2 & E-2 & 76,25 & Tinggi & 18 & E-24 & 71,25 & Sedang \\
\hline 3 & E-30 & 82,5 & Tinggi & 19 & E-5 & 63,75 & Sedang \\
\hline 4 & E-1 & 67,5 & Sedang & 20 & E-6 & 72,5 & Sedang \\
\hline 5 & E-18 & 77,5 & Sedang & 21 & E-15 & 78,75 & Sedang \\
\hline 6 & E-29 & 65 & Sedang & 22 & E-31 & 80 & Sedang \\
\hline 7 & E-20 & 75 & Sedang & 23 & E-9 & 82,5 & Sedang \\
\hline 8 & E-12 & 75 & Sedang & 24 & E-10 & 68,75 & Sedang \\
\hline 9 & E-14 & 72,5 & Sedang & 25 & E-23 & 66,25 & Sedang \\
\hline 10 & E-25 & 61,25 & Sedang & 26 & E-11 & 70 & Sedang \\
\hline 11 & E-17 & 62,5 & Sedang & 27 & E-32 & 70 & Sedang \\
\hline 12 & E-26 & 61,25 & Sedang & 28 & E-28 & 71,25 & Rendah \\
\hline 13 & E-3 & 78,75 & Sedang & 29 & E-7 & 57,5 & Rendah \\
\hline 14 & E-13 & 65 & Sedang & 30 & E-21 & 60 & Rendah \\
\hline 15 & E-19 & 66,25 & Sedang & 31 & E-8 & 73,75 & Rendah \\
\hline 16 & E-9 & 82,5 & Sedang & 32 & E-16 & 67,5 & Rendah \\
\hline
\end{tabular}

Berdasarkan tabel 1 diperoleh bahwa terdapat tiga siswa yang digolongkan self-efficacy tinggi serta terdapat tiga siswa yang memenuhi KKM dan tidak ada siswa yang tidak memenuhi KKM, terdapat juga dua puluh empat siswa yang digolongkan self-efficacy sedang serta terdapat delapan siswa yang memenuhi KKM dan enam belas siswa yang tidak memenuhi KKM dan lima siswa yang digolongkan self-efficacy rendah serta tidak terdapat siswa yang memenuhi KKM, namun terdapat lima siswa yang tidak memenuhi KKM.

1. Kemampuan berpikir kreatif dengan self-efficacy tinggi

Hasil tes kemampuan berpikir kreatif yang tergolong self-efficacy tinggi terdapat tiga siswa, dimana ketiganya memperoleh nilai melebihi KKM. Siswa tersebut yaitu E-22, E-2 dan E-30, dari ketiga siswa tersebut terpilih dua siswa yang telah dianalisis. Setelah diperoleh tiga siswa yang tergolong self-efficacy tinggi maka terpilih satu siswa yang hasil tes kemampuan berpikir kreatif dan angket self-efficacy siswa yang dianalisis. Adapun analisis hasil penelitian dipaparkan sebagai berikut.

Subjek E-30

Hasil tes kemampuan berpikir kreatif diperoleh 82,5, Pada gambar 1 merupakan salah satu hasil pekerjaan siswa. 

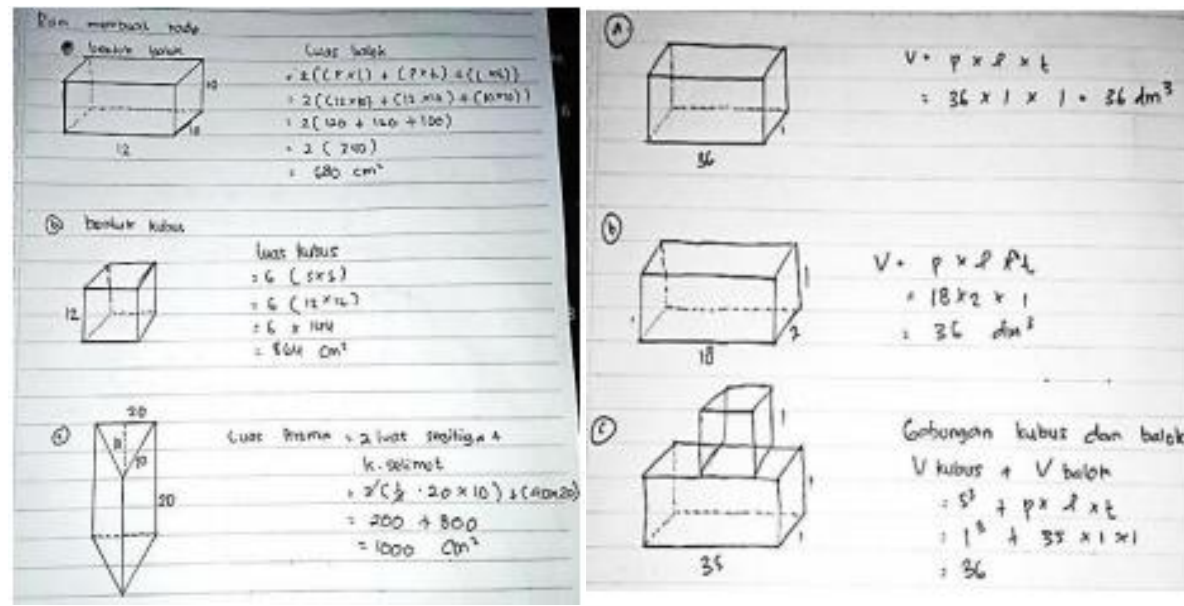

Gambar 1. Pekerjaan soal nomor 1 dan nomor 2 oleh subjek E-30

Berikut adalah analisis kemampuan berpikir kreatif dari subjek E-30 menurut aspek kemampuan berpikir kreatif.

a. Fluency

Subjek E-30 pada aspek fluency atau kelancaran sudah dipenuhi karena subjek E-30 mengetahui informasi yang terdapat pada soal dan mampu menjelaskan cara penyelesaian masalah dengan lancar, tepat, dan jelas. Dari hasil wawancara dengan subjek E-30 menyimpulkan bahwa subjek E-30 mengerjakan soal tersebut dengan rumus yang sudah diketahui. Oleh karena itu aspek fluency subjek E-30 sudah baik.

b. Flexibility

Pada gambar di atas, subjek E-30 sudah memenuhi kriteria flexibility atau keluwesan karena subjek E-30 dapat mengerjakan Tes Kemampuan Berpikir Kreatif (TKBK) dengan berbagai macam cara. Wawancara digunakan untuk menggali informasi lebih dalam, berikut hasil wawancara dengan E-30 dapat disimpulkan bawa subjek E-30 sudah mencapai tingkat keluwesan karena subjek E-30 mengerjakan 3 bangun tersebut karena sudah menghafal rumusnya secara baik walupun ada sedikit kekurangan pada bagian prisma segitiga. Oleh karena itu aspek flexibility subjek E-30 sudah baik.

c. Originality

Hasil tes kemampuan berpikir kreatif nomor 4 dipaparkan pada gambar berikut.

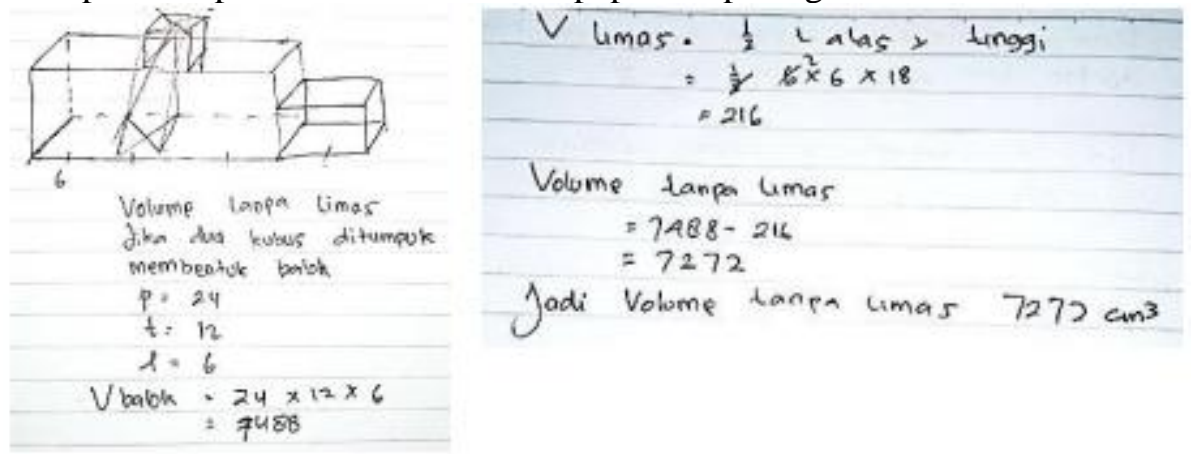

Gambar 2. Pekerjaan soal nomor 4 oleh subjek E-30

Pada gambar 2 Subjek E-30 mengerjakan soal no 4 dengan cara tersebut membuat aspek originality atau keaslian pekerjaan subjek E-30 sudah dipenuhi karena jawaban tersebut belum diajarkan sebelumnya. Untuk menguatkan hal tersebut dari hasil wawancara dengan subjek E30 menyimpulkan bahwa strategi untuk mengerjakan soal gabungan no 2 terinspirasi dari soal no 4 tentang gabungan soal bangun ruang sisi datar, untuk soal no 4 yaitu menentukan volume bangun tanpa prisma yang ada startegi subjek E-30 dengan cara menggeserkan kubus yang di atas balok ke atas kubus di samping balok. Berdasarkan uraian di atas subjek E-30 dapat 
memcahkan soal dengan aspek keaslian dengan baik karena dapat menjawab soal dengan strategi yang tidak diajarkan. Sehingga subjek E-30 memenuhi kriteria originality pada soal no 2 dan 4.

d. Elaboration

Hasil tes kemampuan berpikir kreatif nomor 3 dipaparkan pada gambar berikut.

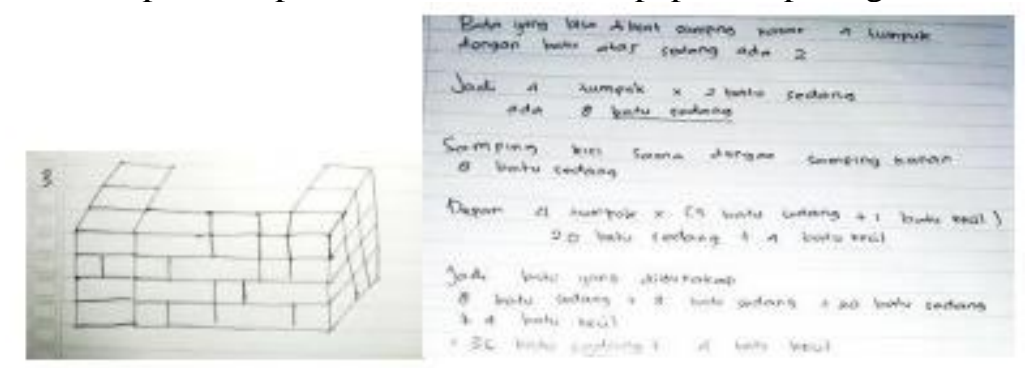

Gambar 3. Pekerjaan soal nomor 3 oleh subjek E-30

Pada gambar tersebut dapat dilihat bahwa subjek E-30 dapat merinci jawaban dengan baik namun masih ada kekurangannya. Untuk menguatkan hal tersebut dari hasil wawancara dengan subjek E-30, menunjukkan bahwa subjek E-30 tidak membuat pekerjaan secara rinci karena takut kehabisan waktu untuk mengerjakan soal no 3. Namun subjek E-30 dapat menjelaskan apa yang tidak dituliskan dalam pekerjaannya, akan tetapi melihat dari pekerjaan dan hasil wawancara oleh karena itu subjek E-30 dapat sudah mampu untuk berpikir kreatif pada aspek elaboration. Berdasarkan analisis data kualitatif di atas untuk kategori self-efficacy tinggi subjek E-30 dapat menyelesaikan Tes Kemampuan Berpikir Kreatif Matematika (TKBKM) dengan nilai yanng melebihi batas tuntas aktual dan dapat mengerjakan tiap-tiap aspek kemampuan berpikir kreatif.

2. Kemampuan berpikir kreatif dengan self-efficacy sedang

Hasil tes kemampuan berpikir kreatif yang tergolong self-efficacy sedang terdapat delapan siswa yang memperoleh nilai melebihi KKM, dan enam belas siswa yang tidak memenuhi nilai KKM. Siswa tersebut yaitu E-1, E-18, E-29, E-20, E-12, E-14, E-25, E-17, E-26, E-3, E-13, E-19, E-9, E-4, E-24, E-5, E-6, E-15, E-31, E-9, E-10, E-23, E-11, E-32 dari ketiga siswa tersebut terpilih dua siswa yang telah dianalisis. Setelah diperoleh dua puluh empat siswa yang tergolong selfefficacy sedang maka terpilih satu siswa yang hasil tes kemampuan berpikir kreatif dan angket self-efficacy siswa yang dianalisis. Adapun analisis hasil penelitian dipaparkan sebagai berikut. Hasil tes kemampuan berpikir kreatif diperoleh 82,5. Gambar berikut merupakan salah satu hasil pekerjaan siswa, subjek E-9.
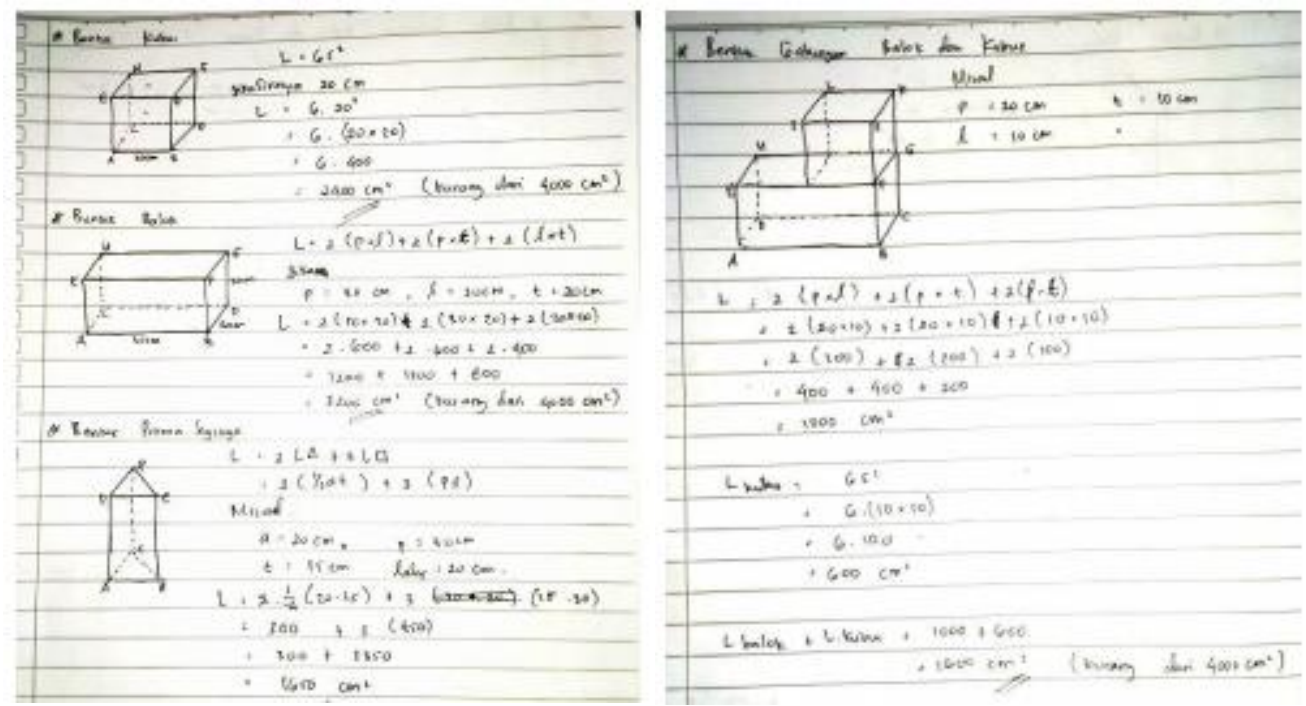

Gambar 4. Pekerjaan soal nomor 1 dan nomor 2 oleh subjek E-9 


\section{a. Fluency}

Aspek fluency atau kelancaran terlihat pada subjek E-9, hasil pekerjaan untuk no 1 Subjek E9 menjawab dengan tepat menegenai luas bangun ruang sisi. Sedangkan pada no 2 berkaitan dengan volume bangun ruang sisi datar subjek E-9 dapat mengerjakan sesuai dengan soal dengan tepat. Untuk menguatkan kesimpulan tersebut dari hasil wawancara dengan subjek E9 , menyimpulkan bahwa dia sudah mampu menjelaskan apa yang dia kerjakan, karena yang dikerjakan sesuai dengan apa yang dituliskan untuk soal no 1 dan 2. Hasil wawancara dapat disimpulkan bahwa subjek E-9 sudah dapat memberi jawaban dengan lancar atau salah satu aspek kemampuan berpikir kreatif matematis yaitu fluency.

b. Flexibility

Pada aspek flexibility terlihat di gambar 5 subjek E-9, sudah dapat memberikan jawaban lebih dari satu jawaban. Lalu untuk menguatkan kesimpulan tersebut berikut hasil wawancara degan subjek E-9, menyimpulkan bahwa subjek E-9 sudah memahami apa kekurangan yang dia kerjakan, oleh karena itu subjek E-9 sudah memasuki tahap flexibility atau keluwesan.

c. Originality

Hasil tes kemampuan berpikir kreatif nomor 4 dipaparkan pada gambar berikut.

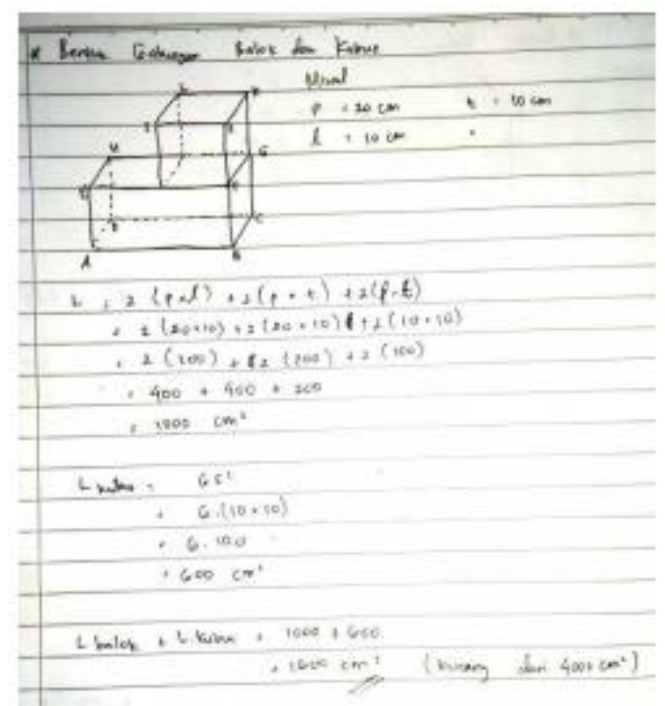

Gambar 5. Pekerjaan soal nomor 4 oleh subjek E-9

Pada tersebut di atas, subjek E-9 menjawab soal no 4, dengan cara mengerjakan yang sudah pernah diajarkan sebelumnya, oleh karena itu kebaruan pada soal nomor 4 belum didapatkan oleh subjek E-9. Hal tersebut subjek E-9 sudah dapat menunjukan kebaruan walaupun masih terdapat kekurangan yaitu pada nomor 4. Untuk menguatkan kesimpulan tersebut dari hasil wawancara degan subjek E-9 menunjukkan bahwa subjek E-9 belum bisa mengerjakan soal dengan cara lain yang belum pernah diajarkan sebelumnya oleh peneliti. Namun subjek E-9 sudah dapat membuat kebaruan pada soal no 2 dan no 4, oleh karena itu dari hasil mengerjakan subjek, hasil wawancara pada aspek fluency dan wawancara pada aspek originality dapat disimpulkan bahwa subjek E-9 sudah dapat membuat kebaruan namun belum terpikirkan kebaruan dari soal yang lebih kompleks.

\section{d. Elaboration}

Hasil tes kemampuan berpikir kreatif nomor 3 dipaparkan pada gambar berikut. 


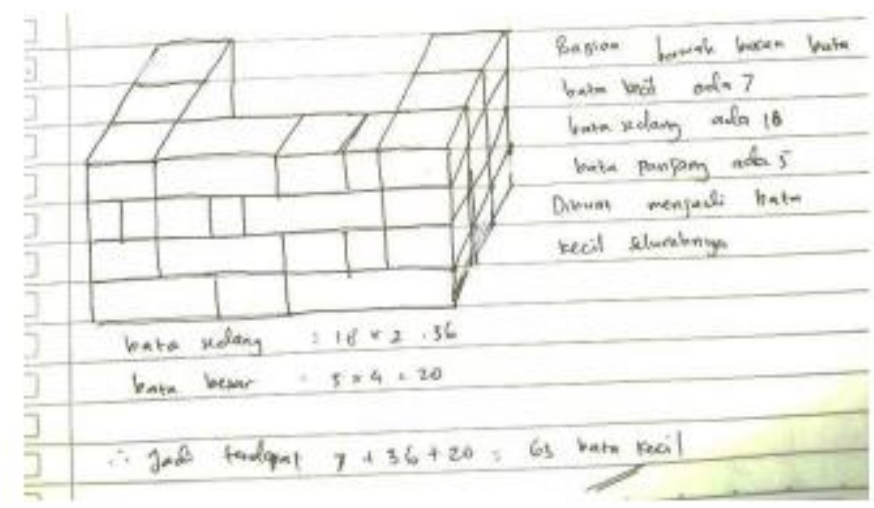

Gambar 6. Pekerjaan soal nomor 3 oleh subjek E-9

Pada gambar di atas, subjek E-9 menjawab soal nomor 4, dengan cara mengerjakan terlihat sudah dapat merincikan hasil jawaban yang dikerjakan. Walaupun hasil jawaban pada nomor 3 masih belum tepat dan gambar tidak sesuai dengan soal, subjek E-9 mampu merinci untuk membuat bata kecil semua dengan mengalikan dua batu yang sedanng dan mengalikan empat batu yang panjang, oleh karena itu subjek E-9 menurut gambar hasil mengerjakan soal sudah dapat merinci. Untuk menguatkan kesimpulan tersebut dari hasil wawancara dengan subjek E9 menunjukkan bahwa subjek E-9 sudah dapat merinci apa yang ditanyakan. Walaupun ada kesalahan pada penghitungan karena menggambar soal tidak sesuai pada jawaban membuat hasil pekerjaan untuk nomor 3 belum sempurna. Berdasarkan analisis data kualitatif di atas untuk kategori self-efficacy sedang subjek E-9 dapat menyelesaikan TKBKM dengan nilai yang melebihi batas tuntas aktual. E-9 mendapatkan nilai yang lebih baik dan dapat menyelesaikan aspek-aspek kemampuan berpikir kreatif.

3. Kemampuan berpikir kreatif dengan self-efficacy rendah

Hasil tes kemampuan berpikir kreatif yang tergolong self-efficacy rendah terdapat lima siswa yang tidak memenuhi nilai KKM dan tidak ada siswa yang memperoleh nilai melebihi KKM. Siswa tersebut yaitu E-28, E-7, E-21, E-8, E-16 dari ketiga siswa tersebut terpilih dua siswa yang telah dianalisis. Setelah diperoleh lima siswa yang tergolong self-efficacy rendah maka terpilih dua siswa yang hasil tes kemampuan berpikir kreatif dan angket self-efficacy siswa yang dianalisis. Adapun analisis hasil penelitian dipaparkan sebagai berikut.

Hasil tes kemampuan berpikir kreatif diperoleh 57. Gambar berikut adalah hasil pekerjaan siswa subjek E-7.

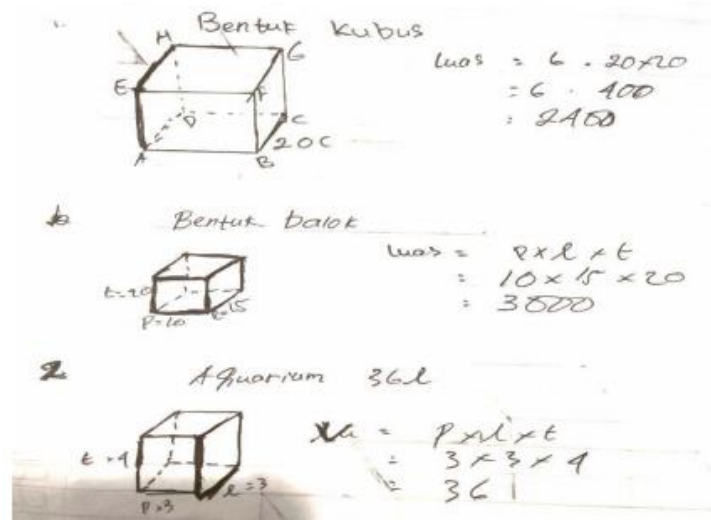

Gambar 7. Pekerjaan soal nomor 1 dan nomor 2 oleh subjek E-7 
Berikut adalah analisis kemampuan berpikir kreatif dari subjek E-7 menurut aspek kemampuan berpikir kreatif.

a. Fluency

Pada gambar 7 di atas, terlihat jawaban nomor 1 dari subjek E-7 membuat dua bangun yaitu balok dan kubus, soal nomor 1 adalah menentukan luas. Namun pada pekerjaan yang terlihat pada gambar subjek E-7 belum menunjukan kelancaran, karena masih terdapat kesalahan menentukan luas balok. Untuk menguatkan kesimpulan tersebut dari hasil wawancara dengan subjek E-7 menunjukkan bahwa E-7 belum lancar dalam menentukan luas permukaan bangun ruang sisi datar pada no 1 . Subjek belum bisa membedakan antara rumus volume dan luas balok. Oleh karena itu dari gambar dan kutipan wawancara di atas dapat disimpulkan bahwa subjek E-7 belum mampu untuk mengerjakan secara lancar dengan baik.

b. Flexibility

Pada gambar 7 terlihat bahwa subjek E-7 tidak bisa membuat berbagai macam jawaban. Subjek hanya membuat 1 jawaban benar pada nomor 1 dan pada nomor 2 subjek E-7 hanya membuat sebuah jawaban yang berkaitan dengan volume. Untuk menguatkan kesimpulan tersebut dari hasil wawancara dengan subjek E-7 menunjukkan bahwa subjek E-7 masih belum bisa dalam menyelesaikan soal kemampuan berpikir kreatif, untuk soal nomor 2 subjek E-7 juga kesulitan dalam menjawab karena E-7 hanya mengerjakan dengan sebuah jawaban saja. Dapat disimpulkan bahwa subjek E-7 pada aspek keluwesan atau flexibility kemampuan berpikir kreatif subjek E-7 belum memenuhi.

c. Originality

Gambar berikut adalah hasil pekerjaan subjek E-7 untuk soal nomor 4.

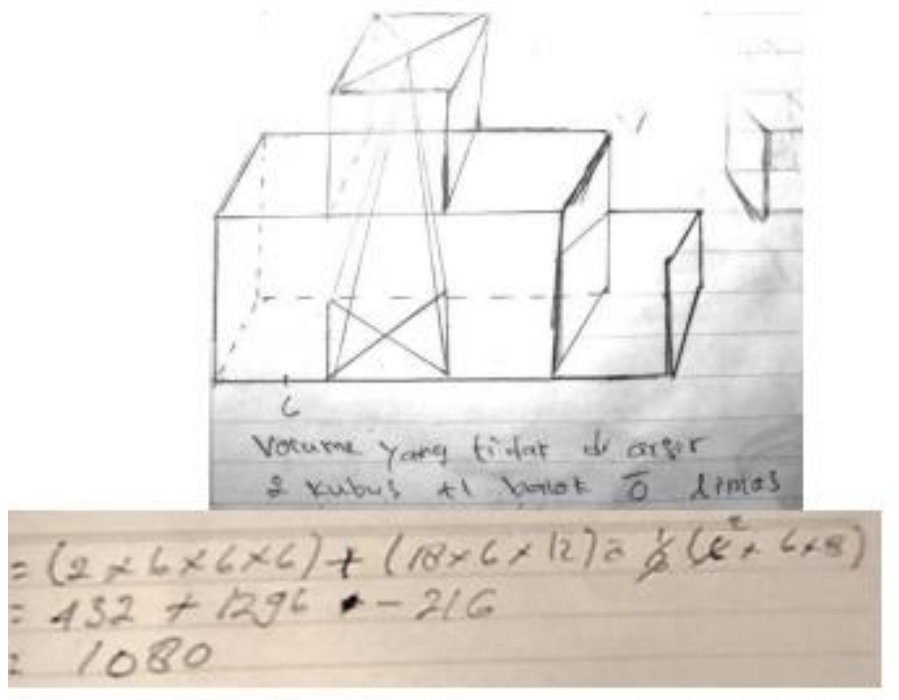

Gambar 8. Pekerjaan soal nomor 4 oleh subjek E-7

Pada gambar di atas terlihat bahwa untuk mengerjakan soal nomor 4 masih seperti cara yang sudah diajarkan sebelumnya. Hasil pekerjaan subjek E-7 juga ada kesalahan pada saat penghitungan. Untuk menguatkan kesimpulan tersebut dari hasil wawancara dengan subjek E7 menunjukkan bahwa subjek E-7 belum mampu untuk berpikir menyelesaiakan masalah dengan cara lain yang sudah diketahui, oleh karena itu berdasarkan gambar serta hasil wawancara pada tahap fluency dan dan originality dapat disimpulkan bahwa subjek E-7 belum bisa mendapatkan hal yang baru atau originality dalam mengerjakan soal tes kemampuan berpikir kreatif matematis.

d. Elaboration

Gambar berikut adalah hasil pekerjaan subjek E-7 untuk soal nomor 3. 


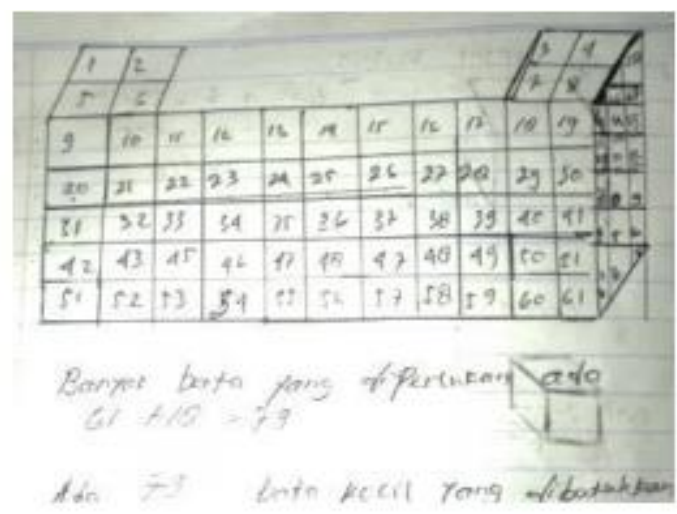

Gambar 9. Pekerjaan soal nomor 3 oleh subjek E-7

Subjek E-7 menyelesaikan masalah pada soal menggunakan tanda angka untuk menentukan batu bata menggunakan batu-batu bata kecil. Namun pada saat penandaan subjek E-7 belum bisa memahami soal karena terdapat bata yang sama diberi tanda nomor dua kali yaitu pada bagian atas. Hal tersebut membuat subjek E-7 belum mampu untuk memecahkan masalah berkaitan dengan bak mandi diselesaikan secara rinci atau elaboration. Untuk menguatkan kesimpulan tersebut dari hasil wawancara dengan subjek E-7 menunjukkan bahwa subjek E-7 belum memahami apa yang dimaksud dengan gambar pada soal, oleh karena itu dapat disimpulkan bahwa subjek E-7 belum mampu untuk merinci jawaban dari soal-soal TKBK. Berdasarkan gambar serta hasil wawancara subjek E-7 belum dapat memenuhi aspek-aspek kemampuan berpikir kreatif yaitu flexibility, originality dan elaboration.

Berdasarkan pemaparan di atas, diperoleh siswa dengan self-efficacy tinggi mayoritas memiliki kemampuan berpikir kreatif matematis yang baik yaitu memenuhi indikator fluency flexibility, originality, dan elaboration. Siswa dengan self-efficacy mayoritas memiliki kemampuan berpikir kreatif yang cukup baik dengan setidaknya memenuhi tiga indikator sedangkan siswa dengan selfefficacy kurang baik hanya memenuhi satu atau dua indikator saja. Pemaparan tersebut sejalan dengan hasil penelitian yang dilakukan oleh Subaidi (2016), bahwa siswa-siswa yang memiliki selfefficacy kuat atau tinggi akan lebih mampu bertahan menghadapi masalah matematika dan tidak putus asa dalam menemui kegagalan. Hal tersebut juga sesuai dengan pernyataan dari Schunk (2012) bahwa siswa yang memiliki efficacy atas pembelajaran dan melakukan tugas-tugas dengan baik, akan berpartisipasi dalam pembelajaran dengan lebih siap, bekerja keras, bertahan lebih lama saat mereka menemui kesulitan, serta dapat memperoleh prestasi yang lebih tinggi.

Adapun menurut Sunaryo (2017) tentang kegunaan self-efficacy adalah membantu seseorang dalam menentukan pilihan, usaha untuk maju, kegigihan dan ketekunan dalam menghadapi kesulitan, dan derajat kecemasan atau ketenangan dan mempertahankan tugas. Jika siswa tidak memiliki selfefficacy yang baik, maka siswa akan menemui kesulitan dalam menentukan menyelesaikan masalah. Hal tersebut sejalan dengan pendapat Liu (2009), bahwa self-efficacy memberikan pengaruh positif terhadap pencapaian prestasi matematika. Jika siswa tidak memiliki self-efficacy yang baik, siswa akan merasa ragu-ragu dalam mengerjakan persoalan dalam matematika. Selain itu penelitian dari Nadia, L. N., \& Isnarto, I. (2017) menyatakan siswa dengan self-efficacy rendah masih mengalami kesulitan dalam menyelesaikan suatu persoalan dengan mengungkapkan ide-ide abstraknya.

\section{SIMPULAN DAN SARAN}

\section{Kesimpulan}

Berdasarkan data temuan penelitian dan pembahasan yang disajikan pada penelitian ini dapat ditarik kesimpulan sebagai berikut: (1) kemampuan berpikir kreatif siswa yang digolongkan berdasarkan self-efficacy tinggi memberikan gambaran bahwa mayoritas siswa memiliki kemampuan berpikir 
kreatif matematis yang baik dimana memenuhi indikator fluency flexibility, originality dan elaboration, (2) memberikan gambaran bahwa kemampuan berpikir kreatif siswa yang digolongkan berdasarkan self-efficacy sedang memberikan gambaran bahwa mayoritas memiliki kemampuan berpikir kreatif yang cukup baik dengan mayoritas setidaknya memenuhi tiga indikator, dan (3) kemampuan berpikir kreatif siswa yang digolongkan berdasarkan self-efficacy rendah memberikan gambaran bahwa belum memiliki kemampuan berpikir kreatif matematif yang kurang baik karena mayoritas hanya memenuhi satu atau dua indikator saja.

\section{Saran}

Adapun saran penelitian ini adalah perlu lebih banyak pertemuannya dalam menyampaikan materi karena masa pandemi yang menyebabkan proses pembelajaran berjalan dengan waktu yang sangat singkat setiap pertemuannya dan perlunya perlakuan ekstra dari guru supaya pembelajaran mendapatkan hasil yang sesuai harapan.

\section{DAFTAR PUSTAKA}

Akgul, S., \& N. G. Kahveci. 2016. "A Study on the Development of a Mathematics Creativity Scale". Eurasian Journal of Educational Research, 52: 57-76.

Bailey, B., T. E. Cooper \& K. Briggs. 2012. "The effect of a modified Moore method on attitudes and beliefs in Precalculus". School Science and mathematics, 112(6): 337-383.

Dewi \& Masrukan. 2018. "Peningkatan Kemampuan Berpikir Kreatif Mahasiswa Program Magister". PRISMA, 1 : 539-546.

Hosnan. 2016. Psikologi Perkembangan Peserta Didik. Bogor: Ghalia Indonesia.

Irmayanti, M., Gusti, N., H., \& Linda, M. 2014. "The Implementation Of Discovery Learning To Teach Speaking At The First Grade Students At Smp Institut Indonesia”. Tell Journa, 3(2): 108114.

Isrok'atun \& Tiurlina. 2014. "Enhancing Students' Mathematical Creative Problem Solving Ability Through Situation-Based Learning”. Mathematical Theory and Modeling, 4(11): 44-49.

Khaerunisak, Kartono, Isti, H., \& Ahmad Y., F. 2017. "the analysis of diagnostic assessment result in pisa mathematical literacy based on students selfefficacy in rme learning". Infinity, 6(1): 7793.

Laili, P., A., \& Rahmanawati, F., Y. 2015. "Pengaruh Persepsi Kompetensi Profesional Guru Matematika Terhadap Self Efficacy Matematika Pada Siswa SMAN 1 Jember" INSIGHT, 11(2): 159-166.

Liliasari, S. Supriyanti, \& M. N. Hana. 2016. "Student's Creative Thinking Enhancement using Interactive Multimedia of Redox Reaction". Jurnal Pengajaran MIPA, 21(1): 30-34.

Liu \& Koirala. 2009. "The effect of mathematics self-efficacy on mathematics achievement of High school students". Nera Conference Proceedings.

Mareta, D., Y., \& Kusumawati D. 2014. "Hands On Activity Approach Through Modified Inquiry To Improve Self Efficacy In Xi Grade Of Sman 1 Tuban Subject Matter Of The Rate Of Reaction". Unesa Journal of Chemical Education. 3(1): 70-75.

Maulidia, F., R. Johar \& Andariah. 2019. " A case study of students' creativity in solving mathematical problems through problem based learning" Infinity, 8(1): 1 -10.

Muhsinin. 2013. "Pendekatan Open-Ended Pada Pembelajaran Matematika". EduMath. 4: 46-59.

Mogapi, M., Waitshega, T., S., M., \& Gaelebelae, N., T. 2017. "Self-efficacy Factor Invariance Across Pre-Service and In-Service Teachers in Botswana". Asian Research Journal of Arts \& Social Sciences, 4(4): 1- 10.

Nadia, L. N., \& Isnarto, I. 2017. Analisis Kemampuan Representasi Matematis Ditinjau dari Self Efficacy Peserta Didik melalui Inductive Discovery Learning. Unnes Journal of Mathematics Education Research, 6(2), 242-250.

Najiha N., L., Budi W. \& Isnarto. 2018. “Analisis Kemampuan Representasi Matematis Ditinjau dari Self Efficacy Peserta Didik melalui Inductive Discovery Learning. Unnes Journal of Mathematics Education Research", 6(2): 242-250. 
Nizam. 2016. HOTS Untuk Membangun Literasi Abad 2. Kepala Pusat Penelitian Pendidikan.

Peng, S., Biing-Lin C., \& Hsueh-Chih C. 2013. "The effect of classroom goal structures on the creativity of junior high school students". Educational Psychology, 33(5): 540-560.

Puspita D. R., A. Nugroho \& Ashadi. 2016. "Penerapan Model Pembelajaran Discovery Learning untuk Meningkatkan Minat dan Prestasi Belajar Siswa Pada Materi Kelarutan dan Hasil Kali Kelarutan Kelas XI Mia 3 Semester Genap SMA N 1 Teras Tahun Pelajaran 2015/2016”. Jurnal Pendidikan Kimia, 5(4).

Putri, I., R. J. Shabrona, \& Ilan N. L. 2017. "Pengaruh Model Pembelajaran Discovery Learning Terhadap Hasil Belajar Siswa Dan Aktivitas Siswa”. Jurnal Pendidikan Fisika, 6(2): 92.

Rahayu, S., M. Mardiyana, \& D,. R,. Sari. 2014. "Eksperimentasi Model Pembelajaran Kooperatif Tipe TAI dan NHT pada Pokok Bahasan Relasi dan Fungsi Ditinjau dari Adversity Quotient (AQ) Siswa Kelas VIII SMP Negeri di Kabupaten Pringsewu Provinsi Lampung”. Jurnal Elektronik Pembelajaran Matematika, 2(3):241 -249.

Riski, M. H., Sukestiyarno \& B. Waluya. 2017. "Creative Thinking Process based on Wallas Model in Solving Mathematics Problem". International Journal on Emerging Mathematics Education (IJEME), 1(2): 177-184.

Rizqi, M. 2020, Analisis Kemampuan Komunikasi Matematika Siswa SMP Bimbingan Belajar Neutron Cabang Banyumanik Semarang. In Senarai Penelitian Seminar Nasional Matematika Ke-11 Universitas Gadjah Mada "Peran Matematika Dalam Pemodelan Risiko Keuangan Yogyakarta, 22 September 2019 (p. 28). Deepublish.

Rizqi, M., Suyitno, H., \& Dwijanto, D. 2021. Efektivitas Pembelajaran Berbasis Masalah dalam Meningkatkan Kemampuan Berpikir Kreatif Matematis Siswa MTS Islamic Center. KoPeN: Konferensi Pendidikan Nasional, 3(1), 300-305.

Rochmad, \& Masrukan. 2016. "Studi Kinerja Mahasiswa Dalam Menganalisis Materi Pada Pembelajaran Kooperatif Resiprokal". Kreano, Jurnal Matematika Kreatif-Inovatif, 7(1): 4757.

Rosidi, I. 2016. "Pengembangan Lembar Kegiatan Siswa Berorientasi Pembelajaran Penemuan Terbimbing (Guided Discovery Learning) Untuk Melatihkan Keterampilan Proses Sains". Jurnal Pena Sains, Universitas Tranjoyo Madura Bangkalan, 3(1): 56.

Saironi, M. \& Sukestiyarno. 2017. "Kemampuan Berpikir Kreatif Matematis Siswa dan Pembentukan Karakter Rasa Ingin Tahu Siswa pada Pembelajaran Open Ended Berbasis Etnomatematika”. Unnes Journal of Mathematics Education Research, 6(1): 76-88.

Schunk. 2012. Learning Theories an educational perspective (8th ed). Boston: Allyn \& Bacon.

Setyosari, H. P. 2016. Metode penelitian pendidikan \& pengembangan. Prenada Media.

Subaidi, A. 2016. "self-efficacy siswa dalam pemecahan masalah matematika". Sigma, 1(2): 64-86.

Sugiyono. 2016. Metode Penelitian Pendidikan Pendekatan Kuantitatif Kualitatif dan R\&D. Bandung: Alfabeta.

Sunaryo, Y. 2017. Pengukuran self-efficacy siswa dalam pembelajaran matematika di MTs N 2 Ciamis. Teorema: Teori dan Riset Matematika, 1(2), 39-44.

Wulandari, I., Y., Sunarto, \& Salman, A., T. 2015. "implementasi model discovery learning dengan pendekatan saintifik untuk meningkatkan kemampuan berfikir kritis dan hasil belajar siswa mata pelajaran ekonomi kelas xi iis i sma negeri 6 surakarta tahun pelajaran 2014/2015". irBISE: Jurnal Pendidikan Bisnis dan Ekonomi, 1(2): 1 -21

Yurniwati, Y., \& Hanum, L. 2017. Improving mathematics achievement of Indonesian 5th grade students through guided discovery learning. Journal on Mathematics Education, 8(1), 77-84. 